$\rightarrow$

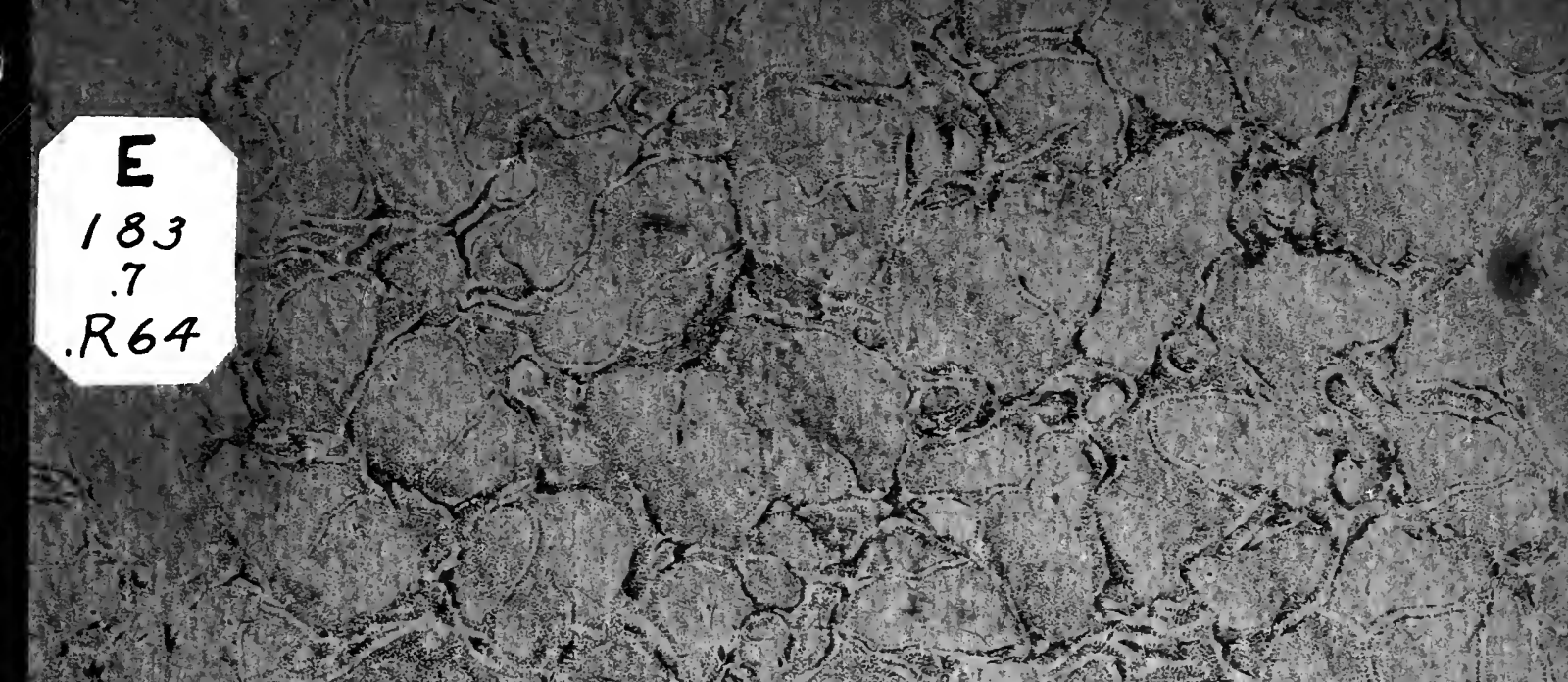

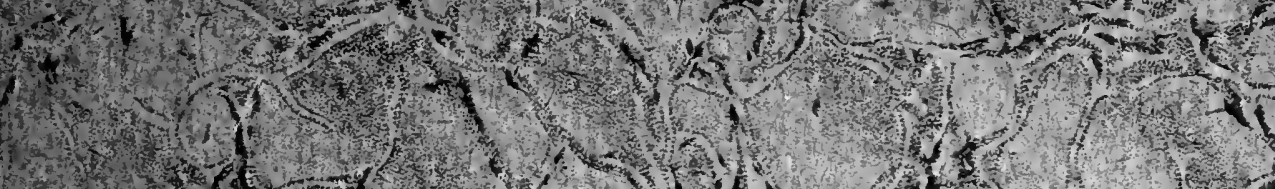

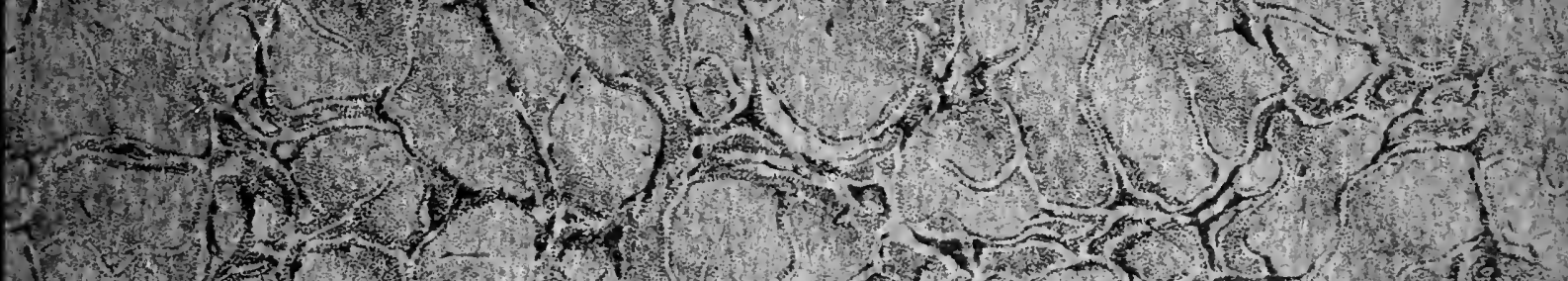

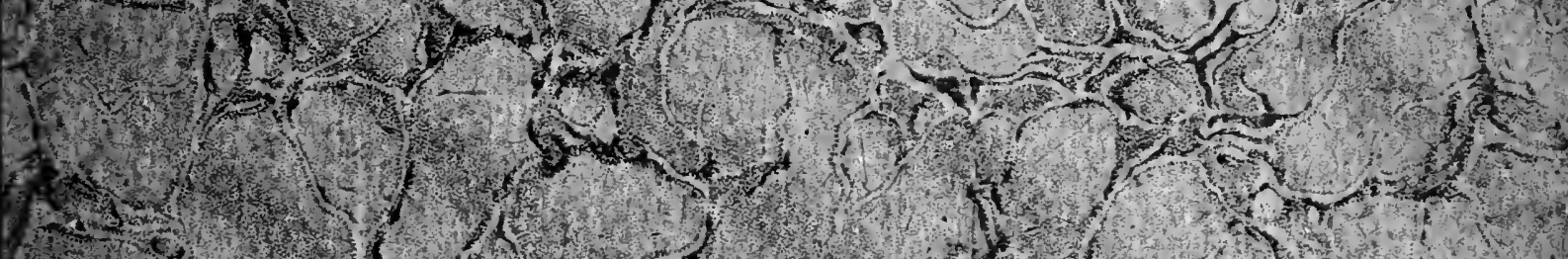
(5).

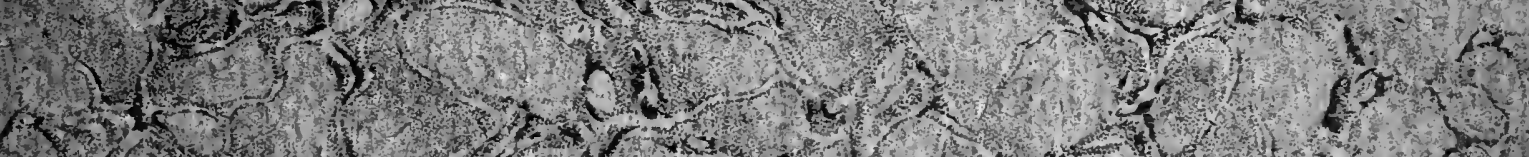
(16)

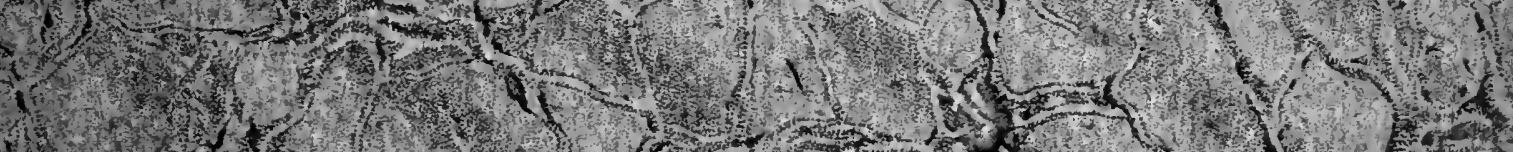
W.

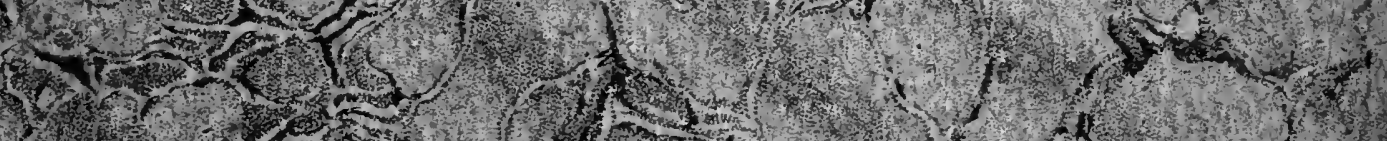

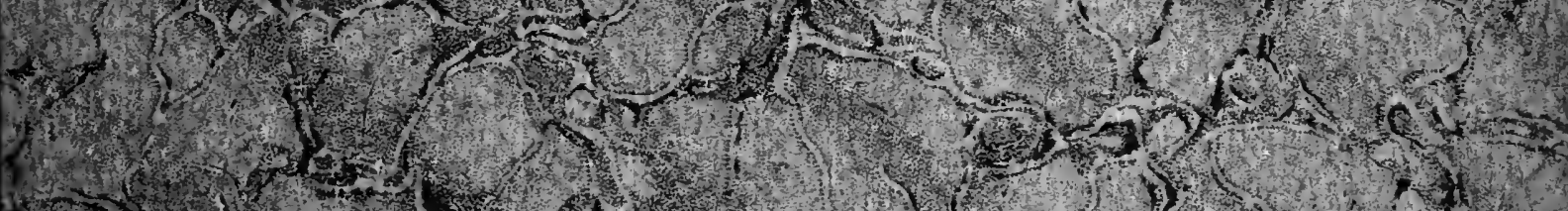

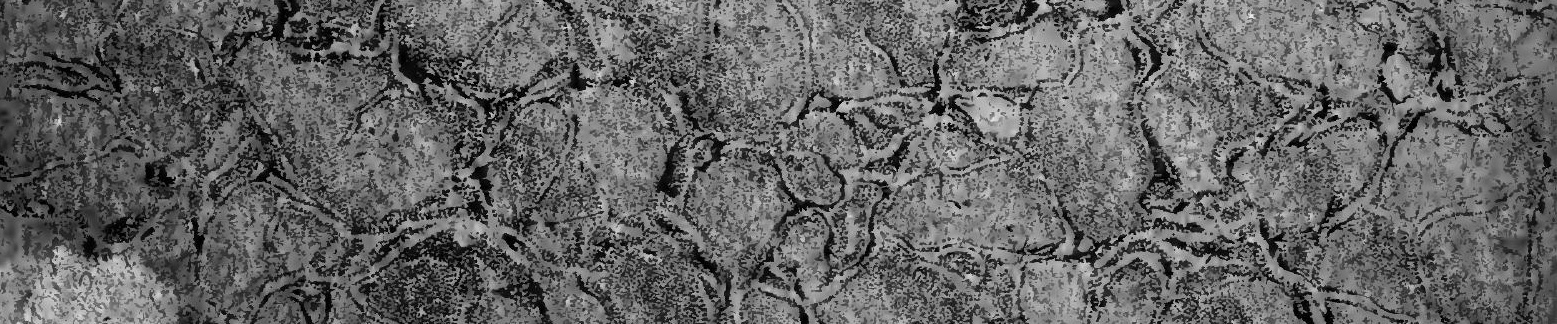

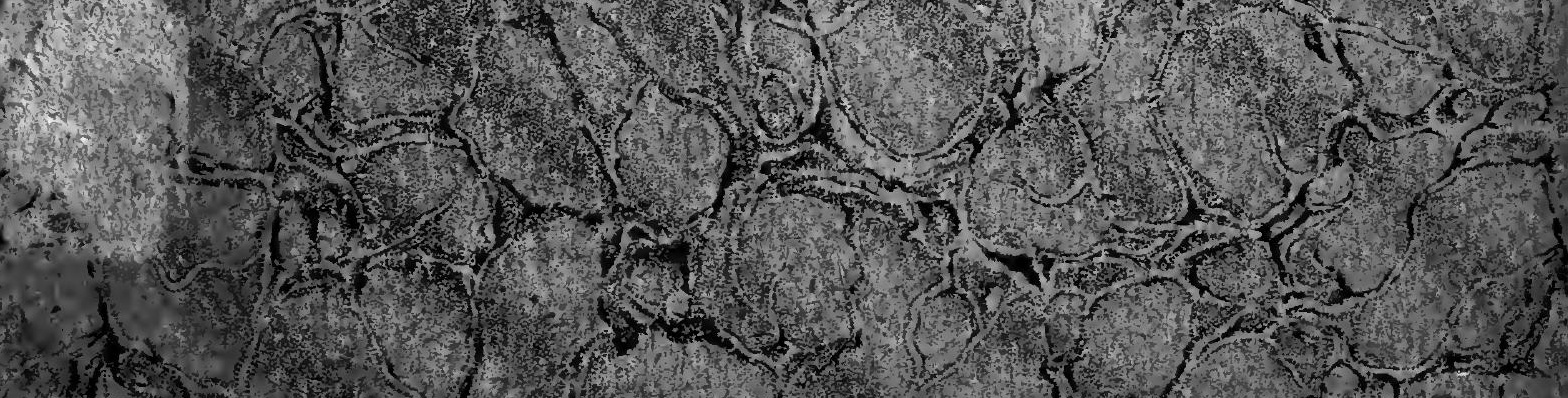




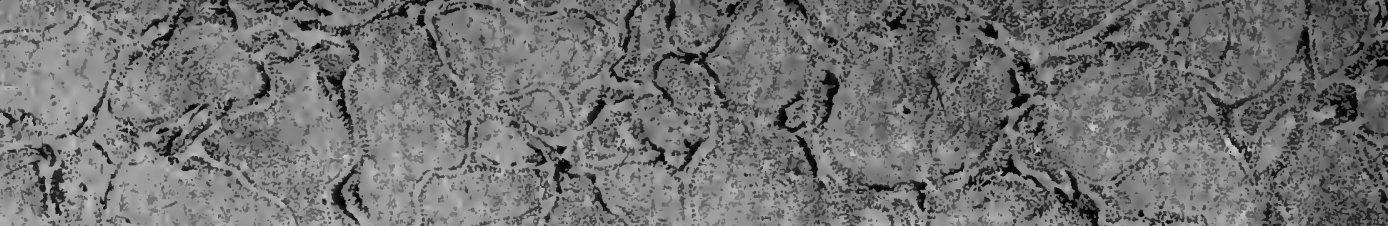

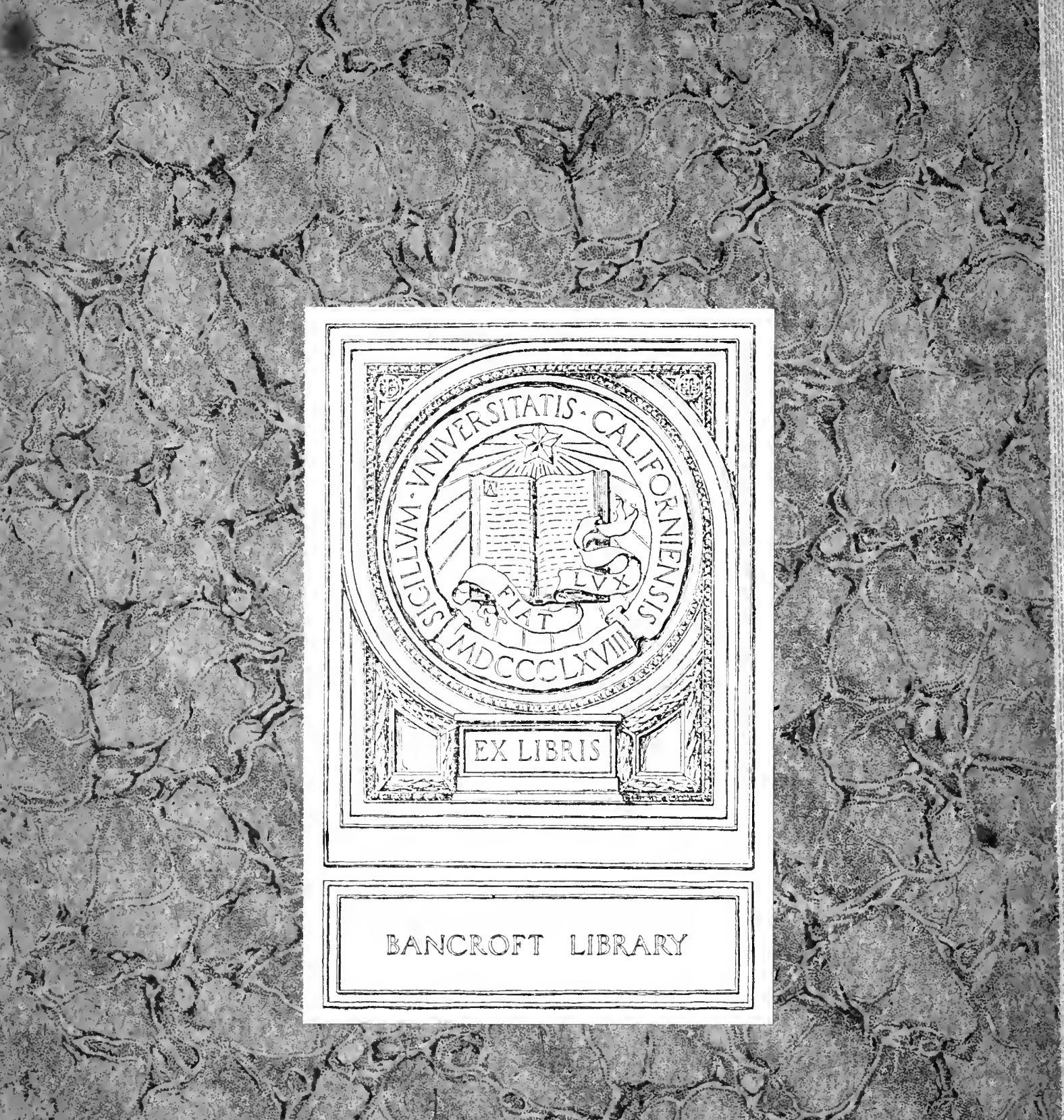

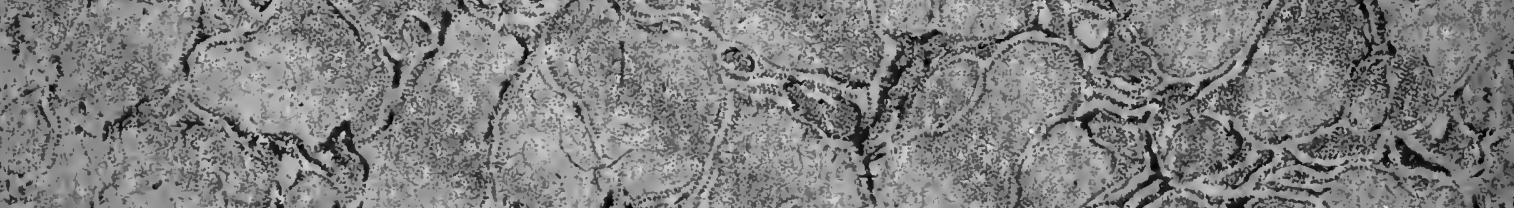
1.5.

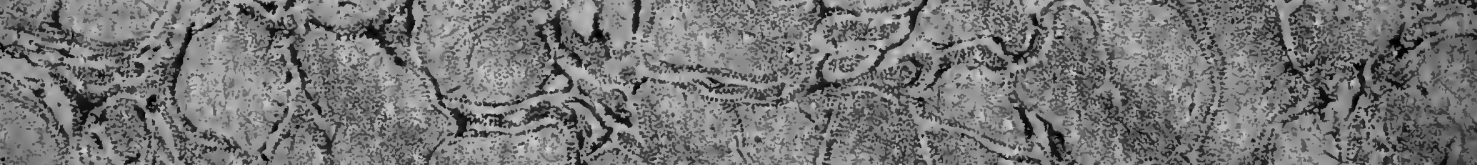

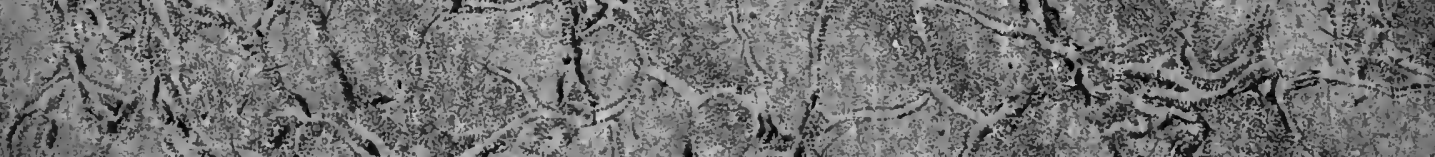
3
6

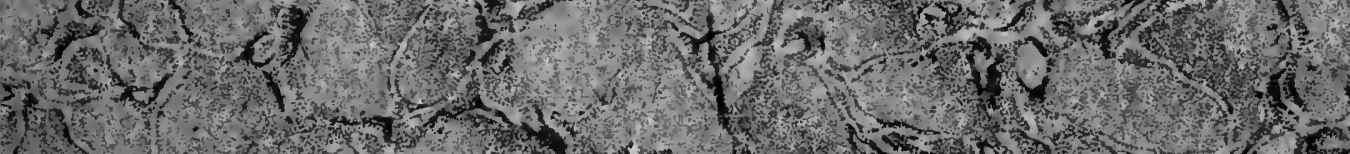




\title{
THE FIRST LEGATIONS OF THE UNITED STATES IN LATIN AMERICA
}

\author{
BY \\ WILLIAM S ROBERTSON
}

Reprinted from the MississippI

Valley Historical Review

Vol. II, September, 1915 


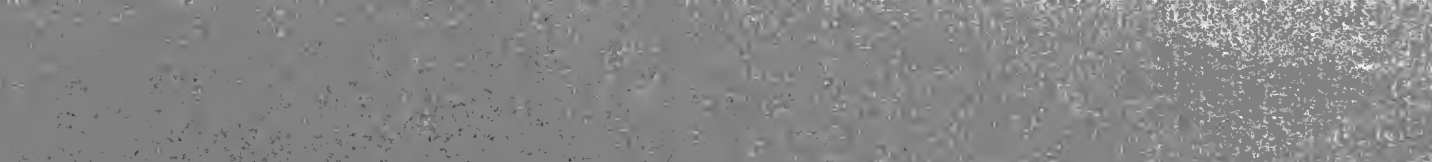

$\therefore,+2$

$4 x-x$

$3 \quad a_{1}$

ard

(n)

41

(1)

a

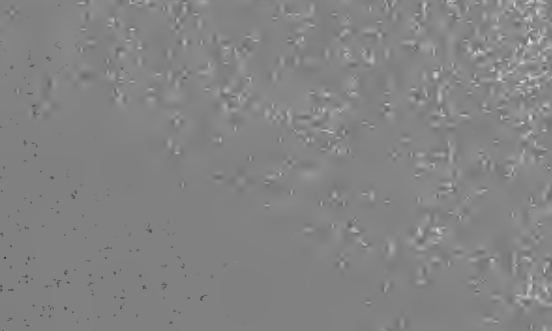

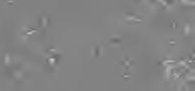

(a)

(n)

a d

ard

(1)

(1)

(a)

and

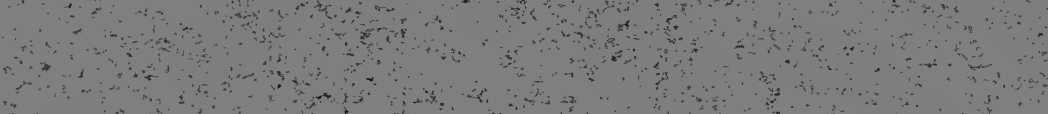

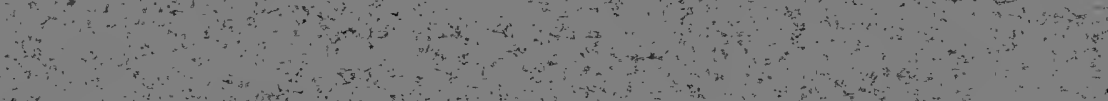

a

(n)

(n)

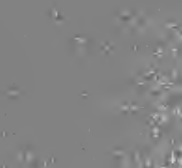

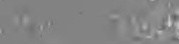

19.98

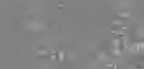

$=8$

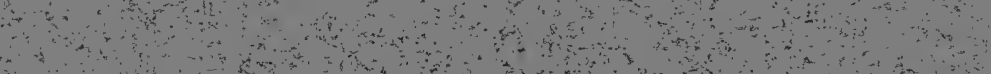
(1)

(n)

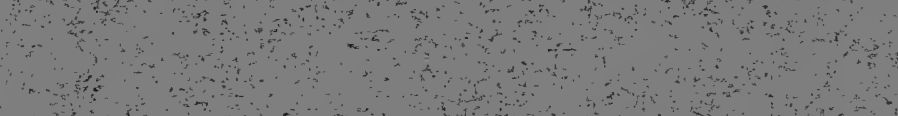


Thith the compliments of
Ir. S. Robertion

THE FIRST LEGATIONS OF THE UNITED STATES IN

LATIN AMERICA 

5183

.7

. R64 
THE FIRST LEGATIONS OF THE UNITED STATES IN LATIN AMERICA

The United States has not always considered herself as the leader of an American family of republics. Many years passed after the adoption of the federal constitution before her statesmen caught the vision of the nation's continental destiny. At the beginning of our national history we faced Europe; later we undertook to plant settlements in the Mississippi valley; recently we have at times turned towards the Orient; we have become the mistress of Porto Rico and the Philippines. At the present time some of our merchants and captains of industry are turning their attention to the nations in the South. Some students of American history and politics perceive that there are in the new world more significant sections than our North, our South, our East, our West; they realize that there exist in America two great sections: Anglo-America, the section profoundly affected by Anglo-Saxon civilization; and Latin America, the region in which live the wayward children of Spain and Portugal.

The revolution, or rather the series of revolutions, which culminated in the establishment of independent states in continental Spanish America was provoked by the usurpations of $\mathrm{Na}$ poleon in the Iberian peninsula. The deposition of Ferdinand VII, king of Spain, was followed by the formation of revolutionary juntas in the Indies. During the second and third decades of the nineteenth century the Spanish empire in America split into states which proclaimed their independence of the mother-land.

In 1822 there could be seen in Spanish America the shadowy outlines of a number of new states. The viceroyalty of Mexico had just been severed from Spain by a bloodless revolution which was accomplished through the promulgation of the sagacious plan of Iguala by the warrior-statesman, Agustín de Iturbide. In northern South America the revolutionary soldiers who followed their dauntless liberator, Simón de Bolívar, had triumphed over the royalists at the battles of Boyaca and Carabobo, and 
delegates from New Granada and Venezuela had adopted a constitution. for "Great Colombia." After the victories of the southern revolutionists guided by their heroic commander, José de San Martín, over the royalists at Chacabuco and Maipo, the captaincy general of Chile had been liberated from Spanish rule. On the Pacific plateau, near the equator, Simón de Bolívar, aided by his indefatigable lieutenant, Antonio José de Sucre, was crowning the military achievements of his rival, José de San Martín, and thus promoting the independence of Peru. On the banks of the Rio de la Plata the citizens of Buenos Aires were striving to form a government for the United Provinces of la Plata - the nucleus of the Argentine nation. But certain sections of the fair viceroyalty of la. Plata had not adhered to the revolutionary movement which had been led by the city of Buenos Aires: la Banda Oriental del Uruguay was a battleground of contending parties; Paraguay was under the sway of that eccentric despot, José de Francia; while the people of Upper Peru, later Bolivia, had not yet formally declared their independence of Spain. And although Mexico, Colombia, Chile, Peru, and Argentina had begun their national existence, yet in Peru, at least, the royalists were still formidable: the decisive struggle between the royalists and the patriots had not taken place: the battle of Ayacucho - the Armageddon of Spain on the continent of South America - was not fought until December 9, 1824.

At an early stage in the wars for independence the revolutionary governments sent agents to the republic of the north to plead for the recognition of the revolted provinces in Spanish America as independent states. As the government of the United States strove to pursue a neutral policy in the struggle between Spain and her colonies, these agents were not received in their official capacity. ${ }^{1}$ But, from 1810 to 1822 , agents were sent from Washington to various sections of South America who were instructed to promote the commercial intercourse between the United States and Spanish America and to make reports concerning the prog-

\footnotetext{
1 The earliest agents sent by the revolted Spanish colonies to the United States are considered in W. S. Robertson, "The beginnings of Spanish-American diplomacy," in F. J. Turner, Essays in American history (New York, 1910), 248-262. For later agents see F. L. Paxson, The independence of the South-American republics (Philadelphia, 1903), 113, 152-157.
} 
ress of the revolutionary movements. ${ }^{2}$ As early as October, 1817, President Monroe laid before his cabinet certain queries in regard to the recognition of the revolted colonies, asking whether the appointment of a minister to a new state should be "considered an acknowledgment of its independence." ${ }^{3}$ While the cabinet delayed a decision upon the mooted question of recognition, Henry Clay won the gratitude of some South Americans by eloquently championing the cause of recognition in congress : on March 24, 1818, he proposed an amendment to the general appropriation bill providing that eighteen thousand dollars be appropriated to send a minister to the provinces of the Rio de la Plata, whenever the president should deem this measure expedient. ${ }^{4}$ In a letter dated August 24, 1818, from John Quincy Adams, the virile secretary of state, to President Monroe, Adams stated succinctly the principle which governed his policy towards the Spanish-American struggles for independence. After declaring that there was a stage in such contests when a neutral state might rightly acknowledge the independence of the revolutionists, the secretary said: "It is the stage when independence is established as a matter of fact so as to leave the chances of the opposite party to recover their dominion utterly desperate." 5

In 1822 President Monroe decided that the time had arrived

2 The first commercial agent appointed to Spanish America was William Shaler, who in the summer of 1810, was made "agent for commerce and seamen" at Vera Cruz. (Secretary Smith to Shaler, June 16, 1810, state department manuscripts, bureau of indexes and archives, Despatches to consuls, 1.) There is no evidence to show that Shaler served as agent of the United States in Mexico at this time, but his instructions evidently served as a model for those of commercial agents who were sent to other parts of Spanish America, as Robert K. Lowry, who was sent to La Guaira, Venezuela. In regard to the other agents of the United States in Spanish America, see Robertson, "Beginnings of Spanish-American diplomacy," in Turner, Essays, 250-252, 258-260; and in Francisco de Miranda and the revolutionizing of Spanish America (American Historical Association, Report, 1907, v. 1), 444, n. a ; and espesially Paxson, Independence of South-American republics, 106-112, 120-124, 161-166.

13 For the attitude of Secretary Monroe towards Spanish America in 1811, see Robertson, "Beginnings of Spanish-American diplomacy," in Turner, Essays, 254, 255, 256. For Monroe's proposals when president in'1817, see J. Monroe, Writings (Hamilton ed. - New York 1898-1903), 6: 31.

4 Annals of congress, 15 congress, 1 session, 2: 1468, 1469.

5 J. B. Moore, A digest of international law (Washington, 1906), 1: 78; "Memorandum upon the power to recognize the independence of a new foreign state," 54 congress, 2 session, Senate executive document 56, p. 52. 
when the United States should acknowledge the independence of the revolted Spanish colonies in America. Accordingly, in response to a request from the house of representatives for information concerning these colonies, on March 8, 1822, Monroe addressed a message to congress declaring that five revolted colonies, Colombia, Chile, Peru, Buenos Aires, and Mexico should be recognized as independent nations and suggesting that congress should make appropriations for diplomatic missions to these countries. After a spirited debate in the lower house, a bill appropriating one hundred thousand dollars to defray the expenses of such diplomatic missions "to the independent Nations of the American continent" as the president might deem proper, passed both houses of congress and was signed by the president on May 4, 1822. President Monroe's message of March 8 provoked an angry protest from Joaquín de Anduaga, the Spanish minister at Washington. A short time afterwards, through its ambassadors the liberal government of Spain presented to the chief members of the holy alliance a manifesto denouncing the policy of recognition which had been announced by the United States, as an attack upon the sacred doctrine of legitimacy. ${ }^{6}$ Spain did not readily abandon her attitude of protest, for long after Ferdinand VII had again become absolute king, his ambassadors at the courts of the leading nations on the European continent were directed to protest vigorously against the recognition of the independence of the Spanish-American states by the reception of diplomatic agents, or by other acts. ${ }^{7}$ And, when Russia learned that Colombia had appointed a diplomatic agent to the court of St. Petersburg, she took occasion to inform the government of the United States that the Czar Alexander, faithful to

6 W. S. Robertson, “The United States and Spain in 1822," in Americal historical review, 20: $781-800$.

7 As illustrations of the policy of Spain after 1823 may be given "Circular dirigido en 21 de enero de 1825 á los agentes diplomáticos de las cortes aliados en Madrid,', protesting against the attitude of England towards Spanish America, archivo general de Indias, estado, América en general, 6; "Protesta dirigida á las potencias extrangeras contra el reconocimiento de América en 5 de mayo de 1828,'” in ibid., 8. See further P. Torres Lanzas, Independencia de América (1st ser. - Madrid, 1912), $5: 562,573$. It was not until December 16, 1836, that the Spanish cortes passed a decree which authorized the government to conclude treaties with the states of Spanish America recognizing their independence and renouncing Spain's right of sovereignty over them. Colección legislativa de España (Madrid, 1818-1889), 21: 584-585. 
the principles which he held in common with his allies, would not receive a minister from any of the de facto governments of Spanish America. ${ }^{8}$ This announcement evoked from Secretary Adams on November 15, 1823, a note to Baron Tuyll, the Russian minister at Washington, in which he justified the action of the United States. Adams declared that in acknowledging the independence of the South American states, the United States was influenced by the considerations which prescribed it as "a duty to independent nations to entertain with each other the friendly relations which sentiments of humanity and their mutual interests" required..

President Monroe had indeed apprehended that the action of the United States in regard to the independence of the SpanishAmerican states might arouse the nations of Europe. In a letter to Jonathan Russell, the chairman of the house committee on foreign relations, on March 12, the president said: "A doubt arises in my mind whether it will be politic to give any distinguished eclat to the recognition until we see its effect on the powers of Europe, who will, I have great cause to presume, be much excited by the measure, from its bearing on legitimacy. . . . It will merit consideration whether it may not be most advisable to appropriate a gross sum for carrying into effect the proposed missions, enumerating the places, to sanction the recognition to that extent, and leave it to the executive to fix the grade, as in appointments to European Courts. If missions of the first grade are sent to all the places, or to more than Mexico, it may be inferred by foreign powers that our object is to organize these new Governments against the Governments of Europe, and thus do the provinces more harm than good, by organizing Europe against them, if not against ourselves. The object is to serve the provinces essentially by promoting the independence of all, with the establishment of free republican governments and, with

8 W. C. Ford, John Quincy Adams; his connection with the Monroe doctrine (Cam. bridge, 1902), 32 ; "Correspondence of the Russian ministers in Washington," in the American historical review, 18: 342. A letter from Juan d'Evereux to Dr. William Thornton, January 17, 1823, announcing his appointment by Colombia as "Envoy Extraordinary and Minister Plenipotentiary to the Courts of Russia, Sweden, and Denmark," is found in the Thornton papers, 1829-1844, in the Library of Congress.

9 Adams to Tuyll, November 15, 1823, state department manuscripts, bureau of indexes and archives, Notes to foreign legations, 3. 
that in view, to obtain their recognition by other powers, as soon as possible." ${ }_{10}$ Indeed before he nominated a single minister to the new governments Monroe heard that certain European diplomats were curious to learn the extent to which the United States intended to carry out the policy of recognition by appointing ministers to the new nations of Spanish America. ${ }^{11}$

In an interpretative note for a reply by Secretary Adams to a query from Mr. Russell, President Monroe clearly indicated that, when congress made an appropriation for the recognition of the independence of the revolted Spanish colonies, the judgment of congress would influence him in determining the scope of his policy. ${ }^{12}$ Soon after the bill was framed providing for diplomatic missions to Spanish America, Adams urged Monroe to determine upon a system of procedure in regard to recognition. $^{13}$ On April 19, the cabinet discussed at length the policy to be followed towards the new states. According to the diary of Adams, one question was "whether Ministers of Plenipotentiary rank should be immediately sent" to all the new governments, or whether the United States should wait "to receive Ministers from them, and return Ministers of the same rank." Crawford, secretary of the treasury, favored "sending immediately four Ministers, without standing upon any point of etiquette." Adams thought that the best course would be "to wait and reciprocate; to receive Mr. Torres as Chargé d'Affaires from the republic of Colombia; to receive the minister from Mexico when he shall arrive, and immediately send one of the same rank in return; to ascertain from the Governments of Colombia, Buenos Ayres, and Chili upon what footing they wish the political relations with us to be placed; and to send Ministers Plenipotentiary whenever they send Ministers of that rank to us." ${ }^{14}$ Several months after this cabinet meeting Adams interpreted the act of

Io Monroe, Writings (Hamilton ed.), 6: 211, 212.

11 On October 22, 1822, Richard Rush, minister of the United States to England, wrote a letter to President Monroe in which he said that the recognition of the independence of the South American states was being discussed in diplomatic eircles in London and that the ministers of the Netherlands and of Denmark had asked him "to which of the new states we had sent a minister."' Monroe papers, 20, in Library of Congress.

12 Monroe, Writings (Hamilton ed.), 6: 212, 213, n. 1.

13 C. F. Adams, Memoirs of John Quincy Adams (Philadelphia, 1874-1877), 5 : 491.

14 Adams, Memoirs of J. Q. Adams, $5: 492$. 
May 4, 1822, to mean that congress had authorized diplomatic missions to five independent nations of Spanish America..$^{15}$ It was probably about the time when the action to be taken in carrying out the policy of recognition was being considered by the cabinet that President Monroe wrote the undated memorandum in which he discussed the status of the Spanish-American republics. He said that, as the new governments had declared their independence and maintained it, and, as the government of the United States had acknowledged their independence, that the United States could regard them "in no other light than that of sovereign and independent nations," which were entitled to all the privileges of other nations. The United States had "a right to trade with them," and they had the right to trade with the United States "subject to no other restrictions," than such as were applicable "to legitimate blockades, and to contraband of war." 16

In March, 1822, Manuel Tórres was the only authorized agent of a Spanish-American government in the United States. ${ }^{17}$ As early as April 22, President Monroe told Adams that he was willing to receive Manuel Tórres officially. ${ }^{18}$ Not until May 23, however, did Adams write to Tórres informing him that, whenever it might suit his convenience and be compatible with the state of his health to visit Washington, President Monroe would receive him "in the character of Chargé d'Affaires from the Republic of Colombia." 19 But, as Tórres was ill, several days elapsed before he could proceed from Hamiltonville, near Philadelphia, to Washington. ${ }^{20}$ On June 18 Tórres informed Adams of his arrival at the capital "in a bad state of health," but willing to call immediately at the department of state. ${ }^{21}$ On June

15 Adams, Memoirs of J. Q. Adams, 6: 101.

16 Monroe papers, 6, in Library of Congress.

17 A part of the correspondence of Torres with the Columbian government is found in P. I. Cadena, Anales diplomáticos de Colombia (Bogotá, 1878), 101-143; his credentials as agent and chargé d'affaires of Colombia to the United States are found in American state papers: foreign relations, $4: 833,834$; on his relations with Adams, see Adams, Memoirs of J. Q. Adams, 5:43, 45-47, 51, 113-116, 186.

18 Ibid., 495.

19 Adams to Tórres, May 23, 1822, state department manuscripts, bureau of indexes and archives, Notes to foreign legations, 3 .

20 Tórres to Adams, June 8, 1822, June 18, 1822, state department manuscripts, bureau of indexes and archives, Notes from Colombian legation, 1.

21 Ibid. 
19, 1822, Adams accordingly presented Tórres, as chargé d'affaires from Colombia, to President Monroe. Adams declared that Tórres, who had "scarcely life in him to walk alone, was deeply affected by it. He spoke of the great importance to the republic of Colombia of this recognition, and of his assurance that it would give extraordinary gratification to Bolivar." President Monroe sat down beside Tórres, "and spoke to him with kindness which moved him even to tears. The President assured him of the great interest taken by the United States in the welfare and success of his country, and of the particular satisfaction with which he received him as its first representative." ${ }^{22}$ Manuel Tórres was thus the first diplomatic representative from the Spanish-American nations to be received officially by the government of the United States : the reception of the invalid chargé of Colombia was the first formal act of recognition by the United States of an American state which had cut adrift from old world monarchies. With the exception of the Portuguese monarchy which was seated at Rio de Janeiro, ${ }^{23}$ the North American republic was the first member of the family of nations formally to recognize the independence of a SpanishAmerican state.

The republic of Colombia, according to the constitution of 1821, included the territories which in colonial days had been under the jurisdiction of the captain general of Venezuela and the viceroy of New Granada. ${ }^{24}$ In 1822 the titular president of "Great Colombia" was Simón de Bolivar, but as he had led his soldiers against the royalists in the presidency of Quito, the able

22 Adams, Memoirs of J. Q. Adams, 6:23; see also the National Intelligencer, June 20, 1822. The services of Tórres in Washington were mentioned by Pedro Gual, the Colombian secretary of foreign affairs, to the congress of Colombia. See Memoria de la secretaría de estado y relaciones esteriores de la repriblica de Colombia leida al primer congreso constitucional el dia 21 de abril del año de 1823 (Bogotá, 1823), 9; also, Moore, International law, 1:90. In ibid. (90-92) a summary is given of the reception by the government of the United States of diplomatic agents from the states of Latin America. On the reception of Tórres, see also Paxson, Independence of South-American republics, 177.

23 Portugal recognized the independence of Buenos Aires in 1821. Registro oficial de la república argentina, $1: 569,570$; J. M. Pereira da Silva, Historia da fundação do imperio brazileiro (Rio de Janeiro, 1870-1871), $2: 280$.

24 J. F. Blanco, Documentos para la historia de la vida pública del libertador de Colombia, Perú, y Bolivia (Caracas, 1875-1877), 8:24-40, prints the Colombian constitution of 1821 which was adopted at Cúcuta. 
vice president, Francisco de Paula Santander, was acting as the chief civil executive of the state. ${ }^{25}$ In Colombia the news of the policy which the United States had announced in regard to the recognition of Spanish-American independence was received with joy. As early as May 9, 1822, Pedro Gual, the Colombian secretary of foreign affairs, had seen a copy of Monroe's message of March 8 and had forwarded the good news to Bolivar. ${ }^{26}$ In the credentials for José M. Sálazar, who was appointed minister to the United States in September, 1822, credentials which were signed by Vice President Santander and Secretary Gual, there was an expression of pleasure that the United States had decided to recognize the independence of Colombia- "a conduct so frank, so noble, and so disinterested." ${ }^{27}$ Meanwhile, an agent, Charles S. Todd of Kentucky, was sent from the United States on a special mission to Colombia as the herald of recognition. ${ }^{28}$ On December 26, 1822, Todd informed Gual of his arrival in Bogotá and congratulated him upon the "signal act" of the United States in recognizing the independence of Colombia. ${ }^{29}$ On January 2, 1823, Gual responded to the effect that Colombia was already aware of the recognition of her independence by the United States and of the reception of Tórres by President Monroe. He said that these two measures had pleased his government, which had never despaired that the United States would be the first to render justice to the Colombians. ${ }^{30}$

Soon after Monroe had expressed to Adams his willingness to receive Tórres as the diplomatic agent of Colombia, a step was taken which foreshadowed the formal acknowledgment of Mexican independence. As early as April 23, 1822, Adams wrote to José M. Herrera, the secretary of foreign affairs for the independent government of Mexico, to announce Monroe's willing-

25 J. Gil Fortoul, Historia constitucional de Venezuela (Berlin, 1907), 1:327, 328.

26 S. B. O'Leary, Memorias del General O'Leary (Caracas, 1879-1888), $19: 256$.

27 Salazar's eredentials as envoy extraordinary and minister plenipotentiary from Colombia to the United States, dated September 1, 1822, are found in the state department manuscripts, bureau of indexes and archives, Notes from Colombian legation, 1.

28 Adams to Todd, July 2, 1822, state department manuscripts, bureau of indexes and archives, Despatches to consuls, 2.

29 Todd to Gual, December 26, 1822 (copy), in state department manuseripts, bureau of indexes and archives, Despatches from Colombia, 2.

30 Gual to Todd, January 2, 1823, ibid. 
ness to receive officially an envoy from Mexico and to declare that the government of the United States would reciprocate by sending an envoy to represent it in Mexico City. ${ }^{31}$ There the liberator, Agustín de Iturbide, had established a provisional government that, according to the plan of Iguala, ${ }^{32}$ was to invite a Spanish prince to occupy the throne of Mexico - a state which included the territory stretching from the Colombian provinces on the isthmus of Panama to the parallel of forty-two degrees north latitude. But in the very month when President Monroe signed the bill providing for the establishment of legations in Spanish America, Iturbide was proclaimed emperor of Mexico with the title of Agustín I. ${ }^{33}$ A short time afterwards President Monroe decided to send Joel R. Poinsett on a mission to Mexico for the purpose of gathering information concerning conditions there. $^{34}$ Poinsett left Charleston on the corvette John Adams with a letter of introduction from Henry Clay to Agustín I..5 While in Mexico City Poinsett had an interview with the emperor who impressed him somewhat unfavorably. ${ }^{36}$ Still, the government of the United States could not postpone the formal acknowledgment of Mexican independence, for Emperor Agustín I soon dispatched a diplomatic agent to Washington. In September, 1822, José M. B. Zozaya, an honorary member of the emperor's council of state, was appointed envoy extraordinary and

31 La diplomacia mexicana (Mexico, 1910-1912), 1:73. Monroe's message to congress of March 8, 1822, recommending the recognition of the independence of certain Spanish-American states had been translated into Spanish and printed in Gaceta extraordinaria del gobierno imperial de México, May 1, 1822, without comment.

32 A manuscript copy of this plan found by the writer in archivo general de México, historia, operaciones de guerra, Iturbide, 4, differs somewhat from the com. monly accepted text. C. M. de Bustamante, Cuadro histórico de la revolución de la América mexicana (Mexico, 1823-1832), 5: carta sexta, 12-15, prints the text of a copy which he presumably secured from the Mexican archives.

33 In A statement of some of the principal events in the public life of Augustin de Iturbide, written by himself (London, 1824-pp. 38-44) is found his account of the events which precipitated the change from a provisional government to imperial rule; see further [V. Rocafuerte] Bosquejo ligerisimo de la revolución de Mégico (Philadelphia, 1822), 230-234.

34 Poinsett to Monroe, July 20, 1822, acknowledged the receipt of Monroe's letter of the eleventh instant, and spoke of his trip to Mexico as an excursion. Monroo papers, 20, in Library of Congress.

35 La diplomacia mexicana, 1:67.

36 J. R. Poinsett, Notes on Mexico, made in the autumn of 1822 (London, 1825), 91-93. 
minister plenipotentiary from the Mexican empire to the United States. $^{37}$ One of the chief objects of this mission, as specified in Zozaya's instructions, was to solicit the government of the United States to recognize Mexico as independent of Spain and as governed by an imperial dynasty. ${ }^{38}$ On December 10, 1822, Zozaya announced to Adams his arrival at Washington; he also sent to the secretary of state a copy of his credentials and expressed a desire soon to meet him. ${ }^{39}$ These overtures were favorably received, and on December 12, 1822, Adams presented Zozaya to President Monroe as envoy extraordinary and minister plenipotentiary from the Mexican empire ${ }^{40}$ this act constituted the formal recognition of the independence of Mexico by the United States.

The recognition of the independence of the other nations of Spanish America was consummated by the appointment of envoys to those countries. In January, 1823, President Monroe nominated diplomatic agents to Colombia, Buenos Aires, Chile, Peru, and Mexico. ${ }^{41}$ On January 27, the senate confirmed the appointment of Richard C. Anderson of Kentucky as minister plenipotentiary to Colombia. ${ }^{42}$ As the first legation of the United States in Spanish America was established at Bogotá, and as the general instructions to the first minister of the United States in Colombia were sometimes cited in the instructions to ministers of the United States in other Spanish-American states, whereas his personal instructions typify those which were given to the

37 La diplomacia mexicana, 1:76-79.

38 Ibid., 82.

39 Zozaya to Adams, December 10, 1822, state department manuseripts, bureau of indexes and archives, Notes from Mexican legation, 1.

40 The National Intelligencer, December 13, 1822; La diplomacia mexicana, 1:94. Cf. Moore, International law, 1:91. On December 13,1822, there was filed in the papers of the department of state the list of eleven persons who were attached to the first Mexican legation at Washington. (State department manuseripts, bureau of indexes and archives, Notes from Mexican legation, 1.) A brief mention of the reception of Zozaya was made in the Gaceta del gobierno imperial de México, February 6, 1823.

11 Senate executive journal, 3:320,325. A summary of the appointments of ministers from the United States to the Latin-American states is given by Moore, International law, 1:90-92. There is found in the Register of the department of state (Washington, 1873 - pp. 50-91), a list of the first diplomatic agents of the United States in Latin America, with the years of their service.

42 Senate executive journal, $3: 327$. 
diplomatic agents of the United States in Latin America during the period under consideration, they will be described in some detail. $^{43}$

It was according to a practice which Secretary Adams had introduced into the department of state, ${ }^{44}$ that Minister Anderson was furnished with both personal and general instructions. The personal instructions dealt with certain details of the mission. Anderson was informed that his salary was nine thousand dollars per annum for all personal and other expenses, with an outfit valued at one year's salary, a quarter's salary for his return to the United States, and an allowance for contingent expenses. The duties of a minister were carefully described. The minister was informed that one of his most important duties was to transmit to his government "accurate information" concerning the policy and the views of Colombia and of "the character and vicissitudes of its important relations with other Powers." He was "to collect and transmit information of every kind, relating to the Government, Finances, Commerce, Arts, Science, and Condition" of Colombia, which might be useful to the United States. He was told of the procedure of his government in drafting and signing treaties. He was directed to send to the department of state the names of all the Colombian ports to which consuls should be appointed, in addition to those consuls who were already stationed at La Guaira and Carthagena. Anderson was to carry on such correspondence with the consuls of the United States in Colombia as he thought "conducive to the public interest." With the consent of the Colombian government, he was authorized to make temporary appointments to fill any vacancies which might occur in these consulates. $\mathrm{He}$ was to exercise great caution in granting passports. He was to accept no presents from the government to which he was accredited. With these instructions Anderson was sent his commission, a letter directed to the president of Colombia, a "full power for negotiating concerning matters of Commerce and Naviga-

\footnotetext{
43 In reality the instructions to the minister to Buenos Aires were written first, the personal instructions to Anderson being modeled upon the instructions to Rodney, mutatis mutandis, but Anderson was the first minister of the United States formally received by an independent Latin-American state.

44 G. Hunt, The department of state of the United States (New Haven, 1914), 331, 332.
} 
tion," a cypher for use in diplomatic correspondence when occasion required, an "engraved design of the uniform worn by the Ministers of the United States at Foreign Courts on occasions when full dress" was required, and letters of credit upon the bankers of the United States in London. There was sent to Baltimore, where Anderson was to embark, a leather trunk containing paper and books for the legation: two reams of dispatch paper, a volume containing the commercial regulations of foreign countries with which the United States had commercial relations, a set of Niles' weekly register, a set of Waite's State papers, and a set of the statutes of the United States. ${ }^{45}$

In his general instructions to Anderson, May 27, 1823, Adams made an exposition of the policy which the United States had pursued towards the Spanish-American revolution. He declared that the "political course of the United States, from the first dawning of South American independence," had been such as was prescribed by her relative duties to all the parties in the revolution. Being at peace with Spain, the United States had "considered the struggles of the colonies for independence as a case of civil war," to which her national obligations obliged her to remain neutral. Her policy, her interests, and her feelings, "all concurred to favor the cause of the colonies . . . ." and while she forebore, as her duties prescribed "from every measure which could justly be construed as hostile to Spain," she had "exercised all the moral influence" which she possessed "to countenance and promote the cause of independence.

When that contest became so manifestly desperate that Spanish Viceroys, Governors, and Captain Generals themselves, concluded treaties with the insurgents, virtually acknowledging their independence, the United States frankly and unreservedly recognized that fact, without making their acknowledgment the price of any favor to themselves, and although at the hazard of incurring the displeasure of Spain." The policy which certain European powers had pursued towards the revolution was unfavorably contrasted with the policy of the United States. Adams also pointed out that the United States had consistently

45 May 28, 1823, state department manuscripts, bureau of indexes and archives, Instructions to ministers, 9; a brief extract from these instructions is printed in Moore, International law, 4:762. 
tried to promote the recognition of the independence of the Spanish-American states by European powers. He mentioned the proposals of certain South Americans for a confederacy of American nations "as a counter-poise to the European Holy Alliance." Adams declared that so far as the proposed confederacy had as its object "a combined system of total and unqualified independence of Europe, to the exclusion of all partial compositions of any one of the emancipated colonies with Spain," the project would have "the entire approbation and good wishes of the United States." That government wished it success so far as its purpose might be "to concert a general system of popular representation for the government" of the Spanish-American states. If, however, the object was to promote a "meeting, at which the United States should preside, to assimilate the polities of the south with those of the north," then the United States desired a more definite statement of the means which were to be used as well as of the end which was desired. Further, Adams declared that the government of the United States was aware that the "recognition of South American independence was not palatable to the taste of any of the European governments. But we felt that it was a subject upon which it became us to take the lead . . . We hope . . . that Europe will be compelled to follow the whole of our example - that is, to recognize without condition and without equivalent. We claim no exclusive privilege for ourselves. We trust to the sense of justice, as well as to the interest of the South Americans, the denial of all exclusive privileges to others." ${ }_{46}$

It was not until December 10,1823, after a long and toilsome journey from La Guaira, that the envoy of the United States caught a glimpse of Bogotá, the capital of Colombia. ${ }^{47}$ On December 12, Anderson notified the Colombian secretary of foreign affairs of his arrival. ${ }^{48}$ Gual replied on the following day: he expressed the gratification of Santander at Anderson's arrival, and declared that the vice president would be pleased to receive Anderson as the minister of the United States at half-past eleven

46 American state papers: foreign relations, $5: 888-897$.

47 Anderson to Adams, December 22, 1823, state department manuscripts, burean of indexes and archives, Despatches from Colombia, 3.

48 Anderson to Gual (copy), ibid. 
o'clock on December 16. ${ }^{49}$ On that day Anderson proceeded to "the flat-roofed house," styled the palace of government, which served as the official residence of Vice President Santander..$^{50}$ There, in the reception room where the viceroys of New Granada had been accustomed to sit, Anderson was presented to Santander. According to the Gaceta de Colombia, on presenting his credentials, the North American made an address; he declared that President Monroe ardently wished to maintain "the relations of perfect harmony and generous friendship" between the United States and Colombia. Vice President Santander responded by complimenting the United States which he characterized as "the classic land of American liberty." Colombian official sentiment in regard to the reception of Anderson was reflected in the Gaceta de Colombia in the following words: "The arrival of the first minister plenipotentiary of the United States in the capital of Colombia cannot fail to inspire the most pleasing sensations in the bosom of every friend of liberty." ${ }^{51}$

On the same day as that on which the senate of the United States confirmed the appointment of Minister Anderson, that body confirmed the appointment of Caesar A. Rodney of Delaware as minister plenipotentiary to the government of Buenos Aires. ${ }^{52}$ As the personal instructions of Adams to Rodney dated May 18, 1823, were the model on which Anderson's were based, it is not necessary to describe them in detail here. Let it suffice to notice some passages in Rodney's general instruc-

49 Gual to Anderson, December 13, 1823, ibid.

50 C. S. Cochrane, Journal of a residence and travels in Colombia during the years 1823 and 1824 (London, 1825), 2:17-20.

51 J. F. Blanco, Documentos para la vida pública del libertador de Colombia, Perú, $y$ Bolivia, 9:161-163; a translation of the excerpt from the Gaceta de Colombia is found in Niles' weekly register, 26:23. Minister Anderson sent a brief account of his reception to Adams, December 22, 1823. (State department manuscripts, bureau of indexes and archives, Despatches from Colombia, 3.) After some negotiations, on October 3, 1824, Anderson and Gual signed a treaty of amity, commerce, and naviga. tion between the United States and Colombia, the first treaty negotiated by the United States with an independent state of Latin America. W. M. Malloy, Treaties, conventions, international acts, protocols and agreements between the United States of America and other powers, 1:292-301. With regard to the attitude of Colombia towards the message of President Monroe to congress of December 2, 1823, see W. S. Robertson, "South America and the Monroe doctrine," in Political science quarterly, $30: 83-92$.

52 Senate executive journal, $3: 327$. 
tions which express the ideas of the secretary of state concerning the significance of the revolution which had taken place in South America and the spirit which he thought should animate the diplomatic representatives who were sent from Washington to the new states: "The establishment of Independent nations and Governments in South America forms a remarkable aera in the History of the world, and the formal interchange of diplomatic Missions with them is a memorable event in that of our own Country. . . . With relation to Europe there is perceived to be only one object, in which the interests and wishes of the United States can be the same as those of the Southern American Nations and that is that they should all be governed by Republican Institutions, politically and commercially independent of Europe. To any confederation of Spanish American provinces for that end, the United States would yield their approbation, and cordial good wishes. . . . We have not commanded, nor would we have accepted special privileges for an acknowledgment of Independence. But that which we have not desired and would not accept for ourselves, we have a right to insist ought not to be granted to others. Recognition is in its nature, not a subject of equivalent; it is claimable of right, or not at all. You will therefore strenuously maintain the right of the United States to be treated in every respect on the footing of the most favored; or it is more properly expressed, the most friendly nation - Gentis amicissima; and should you negotiate a Treaty of Commerce you will make that principle the foundation of all its provisions. . . . Our intercourse with Buenos Ayres, as with all the other new Nations of this Hemisphere, is of recent origin; formed while their own condition has been altogether Revolutionary; and continually changing its aspect. Our information concerning them is imperfect, and among the most important objects of your Mission will be those of adding to its stores; of exploring the untrodden ground, and of collecting and transmitting to us the knowledge by which the friendly relations between the two Countries may be extended and harmonized to promote the welfare of both, with due regard to the Peace and good-will of the whole family of civilized man . . . In all your consultations with the Government to which you will be accredited, bearing upon its political relations with this Union, 
your unvarying standard will be the spirit of Independence, and of Freedom: as equality of rights and favors will be that of all its commercial Relations.", 53

In the middle of November, 1823, Rodney disembarked at the city of Buenos Aires. At that time the United Provinces of la Plata did not possess a real national government. The governor of the important littoral province of Buenos Aires, General Martín Rodríguez, was acting as the chief executive of the so-called United Provinces. ${ }^{54}$ On November 18, the government of the province of Buenos Aires issued a decree proclaiming that, by virtue of the credentials which Rodney had brought, he was recognized as minister plenipotentiary of the United States. ${ }^{55}$ The serious illness of that minister, however, prevented him from being presented to Governor Rodríguez for several weeks: on December 27, Rodney proceeded to the government building, where, in the presence of the chief officials of the province, he was formally presented to Rodríguez. ${ }^{56}$ According to the report which Rodney sent to Monroe, that minister made an address in which he declared that "in recommending spontaneously, to Congress, the decided step of recognizing the Independence of the Governments, South of the U. States," President Monroe "was influenced by the purest motives and the most just and generous principles; supported by the almost unanimous vote of the virtuous representatives of the nation, and the voice of a free and enlightened people." In reply, Bernardino Rivadavia,

53 May 17, 1823, state department manuscripts, bureau of indexes and archives, Instructions to ministers, 9.

54 L. V. Varela, Historia constitucional de la república argentina (La Plata, 1910), $3: 392$.

55 Registro oficial de la república argentina, $2: 46$.

56 Rodney to Adams, May 22, 1824, state department manuscripts, bureau of indexes and archives, Despatches from Buenos Ayres, 2. On December 23, 1823, General Carlos de Alvear, who had been supreme director of the government at Buenos Aires, was appointed minister plenipotentiary to the United States. (Registro oficial de la república argentina, 2:48.) He appeared in Washington early in October, 1824; and his credentials, which indicated that he had been appointed largely because of the mission of Rodney, were filed with the department of state. (M. Rodríguez and B. Rivadavia to the president of the United States, January 5, 1824, state department manuscripts, bureau of indexes and archives, Notes from Argentine confederation and Buenos Aires, 1.) It does not appear however that Minister Alvear was presented to President Monroe: he soon left Washington for South America, having been appointed minister to Colombia. Registro oficial de la república argentina, $2: 65$. 
the talented secretary of foreign affairs for Rodríguez, said that this action of "the great and good" Monroe was "above all praise"; he declared that the recognition of the independence of Buenos Aires by the United States "was the most important event in the history of his country." ${ }_{57}$

On January 27, 1823, the senate of the United States also confirmed the appointment of Heman Allen of Vermont as minister plenipotentiary of the United States to Chile. ${ }^{58}$ Besides his own general and personal instructions, Allen was furnished with copies of the general instructions to Rodney, as well as those to Anderson: these instructions he was to consider as addressed to himself upon any point to which they might be applicable. ${ }^{59}$ In supplementary instructions to Allen dated November 30, 1823, Adams said, speaking of the objects of the diplomatic missions to Chile and Peru: "These objects are the establishment of the most friendly relations with the people of those Countries, under their new Republican Institutions : the manifestation of a warm and cordial sentiment of favor and sympathy to the cause in which they are engaged, so far as that sentiment can be indulged, consistently with our neutrality, and the firm and fearless support of the rights and lawful interests of the United States and of their citizens." 60

In April, 1824, Allen arrived at Santiago de Chile. At that time, General Freire, who became supreme director of Chile after the abdication of the revolutionary leader, Bernardo O'Higgins, was absent from the capital, for he had taken command of an expedition which had been sent against the Spaniards in the Chiloé islands. As his substitute, Freire had left

57 " Substance of the address of the minister to B. Ayres, to the Governor of that Republic with his reply,' addressed to James Monroe, Monroe papers, 20, in Library of Congress. A description of the reception of Rodney by the government of Buenos Aires, taken from a gazette of that eity, is found in the National Intelligencer, April 7, 1824. With regard to the attitude of the government of Buenos Aires towards the Monroe doctrine at this time see Robertson, "South America and the Monroe doctrine,' in Political science quarterly, 30:98-104.

58 Senate executive journal, $3: 325,327$.

59 The general instructions of Adams to Allen, dated November 23, 1823, are found in state department manuscripts, bureau of indexes and archives, Instructions to ministers, 10 ; extracts from these instructions are printed in Monroe, Writings (Hamilton ed.), $6: 399-401$.

60 State department manuscripts, bureau of indexes and archires, Instructions to ministers, 10 . 
Fernando Errázuriz at the head of the government. ${ }^{81}$ In the end of April, 1824, Minister Allen was formally received at Santiago de Chile by Acting Supreme Director Errázuriz. According to his dispatch to Adams, on this occasion Allen made an address in which he declared that the United States "at a time, best calculated to give effect to the act, in the most solemn and unconditional manner, recognized the independence of Chili, and commissioned me as its Representative, to reside near its Court, for the purpose of cultivating the relations of peace and friendship, and for the interchange of mutually kind offices, on terms of the most perfect reciprocity, between the two nations." $\mathrm{Al}$ len also reported to Washington that, in an interview with Juan Egaña, the Chilean minister of foreign affairs, that minister had declared that the Chilean government "had uniformly regarded the United States, as its best and most powerful friend, and that with its conduct, throughout her revolutionary struggle, she had experienced nothing but the most entire satisfaction - that the act of recognition, and the subsequent acts of our government, and lastly the President's Message, had cheered all hearts; and that great benefits were anticipated from the intercourse which was about to be opened between the Two Nations." ${ }^{2} 2$

Of the South American states which presumably came within the purview of the act of May 4, 1822, Peru was the last to receive a diplomatic agent from the United States. On April 11, 1826, James Cooley of Ohio was nominated by President Adams chargé d'affaires of the United States to Peru : this appointment was confirmed by the senate on May $2 .{ }^{63}$ Cooley's general instructions dated November 6,1826 , were written by Henry Clay, who had become secretary of state under President Adams. These instructions declared that it was Cooley's "duty generally, to take care of the interests of the United States, and of their Cit-

61 D. Barros Arana, Historia jeneral de Chile (Santiago, 1884-1902), 14:365-368.

62 The message which Egaña thus referred to was Monroe's message to congress of December 2, 1823. On April 29, 1824, Allen sent a copy of his address, marked A, with the dispatch announcing his reception, to Adams. State department manuscripts, bureau of indexes and archives, Despatehes from Chile, 1. See further Niles' weekly register, 26:398; Barros Arana, Historia jeneral de Chile, 14:367, 368.

63 Senate executive journal, 3:528, 534. On January 13, 1823, President Monroo had nominated John B. Prevost as chargé d'affaires to Peru, but this nomination was soon withdrawn. Ibid., 320,340 . 
izens . . . The wish of the President is to establish the most amicable relations with the Republic of Peru, and, on all occasions, to cultivate that harmony and good will which should prevail between the United States and that Republic." ${ }_{64}$ The chargé of the United States arrived in Lima, the capital of Peru, on May 15, 1827, ${ }^{65}$ several months after Bolívar, the liberator of Colombia, Peru, and Bolivia, had left Lima for Bogotá. During the interval which elapsed between the departure of Bolívar and the meeting of a constituent congress, the government of Peru was in the hands of a council of government. ${ }^{66}$ On May 21, 1827, the chargé d'affaires of the United States was formally presented to General Santa Cruz, a soldier of the revolution who was acting as the president of the council of government. On that occasion Santa Cruz expressed his pleasure at receiving the representative of such a "great" and "magnanimous" nation "a nation whose example they were all trying to imitate. . . ." In reply, Cooley expressed his gratification at these remarks; he voiced the desire of the United States to establish "the most amicable relations" with the republic of Peru; he spoke of the interest which the United States took in the welfare of the Peruvian state, and expressed the hope that his mission might "render solid and lasting the friendly relations which existed between the two Republics." ${ }_{67}$

The establishment of a legation of the United States in Mexico City was somewhat retarded by the reluctance of the government to send a minister to an American empire. Two men were successively appointed to the post but did not serve. ${ }^{68}$ Meanwhile, a political transformation took place in Mexico. In March, 1823, the Emperor Agustín I resigned his throne; soon

64 State department manuscripts, bureau of indexes and archives, Instructions to ministers, 11.

65 Cooley to Clay, May 22, 1827, state department manuscripts, bureau of indexes and archives, Despatches from Peru, 1.

66 C. R. Markham, A history of Peru (Chicago, 1892), 284.

67 Cooley to Clay, May 22, 1827, state department manuscripts, bureau of indexes and archives, Despatches from Peru, 1.

68 Andrew Jackson declined the appointment in a letter to Adams, March 15, 1823; Ninian Edwards resigned the position in a letter to Adams, June 22, 1824. State department manuscripts, bureau of indexes and archives, Despatches from Mexico, 1. On these appointments see further, Adams, Memoirs of J. Q. Adams, 6:128, 129, 249, 262, 296-307; 339, 370-376, 386-393; Monroe, Writings (Hamilton ed.), $6: 307$. 
afterwards he became an exile from his native land. ${ }^{69}$ On October 4,1824 , a constituent congress which assembled in Mexico City promulgated a constitution for the United Mexican States which much resembled the constitution of the United States. ${ }^{70}$ Perhaps it was this change in the form of government which induced President Monroe to nominate Joel R. Poinsett of South Carolina envoy extraordinary and minister plenipotentiary to Mexico, an appointment which was confirmed by the senate on March 8, 1825. ${ }^{71}$ The general instructions of Secretary Clay to Minister Poinsett were dated March 26, 1825. In these instructions the minister was told that he undertook an important mission, for he was the first minister of the United States to a sovereign power of the North American continent whose dominions were coterminous with the territories of the United States. Clay declared that the chief purpose of this mission was "to lay, for the first time, the foundations of an intercourse of amity, commerce, navigation, and neighborhood, which may exert a powerful influence, for a long period, upon the prosperity of both States." Poinsett was informed that his conduct was to be guided by the general instructions of Adams to Minister Anderson, which he was to consider as being incorporated in his own, so far as they were applicable. The secretary of state of the United States declared that his government asked no favors because it had recognized the independence of Mexico at an early date; but he said that this action should induce Mexico to deny "to the commerce and navigation" of European states "any favors or privileges which shall not be equally extended to us." For guidance in negotiating a treaty with Mexico, Poinsett was given a copy of the treaty which had just been negotiated between the United States and Colombia; but he was to substitute for the most favored nation rule which had been adopted as the basis for the Colombian treaty "that of placing the commerce and navigation of the two countries on the more liberal footing of reciprocity between the resident citizens and the foreigner,"

69 C. M. de Bustamante, Continuación del cuadro histórico: historia del emperador D. Agustin de Iturbide (Mexico, 1846), 125-128, 135, 136.

70 Colección de ordenes y decretos de la soberano junta provisional gubernativa y soberanos congresos generales de la nación mexicana (Mexico, 1829), 3:79-106.

71 Senate executive journal, 3:441, 443, 444. 
which was provided for by the act of January 7, 1824. Poinsett was directed to bring to the attention of the Mexican government the president's message to congress of December 2, 1823, announcing the Monroe doctrine. He was instructed that the United States did not wish to see Cuba transferred to any European state or made a dependency of any Spanish-American state. If Cuba was to become a dependency of any American state, the "law of its position" proclaimed that "it should be attached to the United States." ${ }^{2}$

On June 1, 1825, the first minister from the United States was officially received in Mexico City by President Guadeloupe Victoria, a leader of the revolution who had just become president. At this reception there were present the diplomatic representatives of certain foreign powers, the secretaries of the Mexican government, and deputations from various corporations of Mexico City. After presenting his credentials, Poinsett made a speech in which he aimed to place the conduct of the United States toward Mexico "in its true light." He declared that the United States regarded "with deep interest the political movements" in Mexico; that "with unfeigned satisfaction" she had seen the only free government which adjoined her "erect itself into a sister republic"; and that the United States was pleased that Mexico had adopted "a Federal Constitution so similar" to lier own. He briefly described the policy which the United States had followed in regard to the recognition of the independence of Spanish America: "In this act of recognition, they took the lead of the whole civilized world, and gave an example which has since been followed by the freest government of Europe." He mentioned Monroe's message to congress of December 2, 1823, as containing a declaration on the part of the United States that "they would not regard with indifference any attempt on the part of the powers of Europe" to wrest independence from the new American states. According to Poinsett's dispatch to Clay, in reply President Victoria declared that Mexico and the United States were bound together by territorial contiguity, by

\footnotetext{
72 The general instructions to Poinsett, dated March 26, 1825, are found in state department manuscripts, bureau of indexes and archives, Instructions to ministers, 10; extracts from these instructions are found in Register of debates, 17 congress, 1 session, pt. 1, ap., 83, 84; American state papers: foreign relations, $6: 578-581$, where the date of the instructions is given as March 25.
} 
their common liberty, by their fundamental law, and by their common interests - bonds which "identified the fortune and the destiny of the United States of North America with the destiny and fortune of Mexico." ${ }^{73}$ It does not appear that Poinsett's speech evoked from Victoria any allusion to the Monroe doctrine.

After the downfall of Agustín I, the provinces of Central America had separated from Mexico, and proclaimed their independence. ${ }^{74} \quad$ A short time afterwards Antonio José Cañas was appointed envoy extraordinary and minister plenipotentiary from the United Provinces of Central America to the United States. In July, 1824, Cañas appeared in Washington, where, on August 4, 1824, he was presented by Secretary Adams to President Monroe as the minister from Central America. On this occasion Cañas did not deliver any address, perhaps because he could not speak the English language. ${ }^{75}$ Probably the most important question which was considered by Minister Cañas and Secretary Clay was the proposal of the Central American that the United States and Central America should coöperate in opening a transisthmean canal through the province of Nicaragua. ${ }^{76}$

Clay's general instructions to John Williams, the first chargé d'affaires of the United States to Central America, were signed on February 10, 1826. On arriving in Santiago de Guatemala, the chargé was to present to the government for ratification the treaty of amity and commerce which Clay and Cañas had just signed. Williams was instructed to gather such information as might aid the United States in making a decision with regard to the proposal of Cañas concerning a transisthmean canal. One

\footnotetext{
73 Poinsett to Clay, June 4, 1825, incloses a copy of his speech to President Victoria and of the latter's reply. State department manuscripts, bureau of indexes and archives, Letters from Mexico, 1. J. M. Bocanegra, Memorias para la historia de México independiente (Mexico, 1892 $\rightarrow 1: 379-383$ ), prints an account of Poinsett's reception from La águila mexicana, June 3, 1825, and the speeches of Poinsett and Victoria. With regard to Mexico and the Monroe doctrine at this time see W. R. Manning, "Statements, interpretations, and applications of the Monroe doctrine and of more or less allied doctrines from 1823 to 1825," in Proceedings of the American Society of International Law at its eighth annual meeting, 34-52.

74 La diplomacia mexicana, 2: 216-219.

75 Adams to Cañas, July 10, 1824, state department manuscripts, bureau of indexes and archives, Notes to foreign legations, 3 ; Adams, Memoirs of J. Q. Adams, 6: 405, 406.

76 Ibid., 530. Clay to Cañas, April 18, 1825, state department manuscripts, bureau of indexes and archives, Notes to foreign legations, 3 .
} 
of the great objects of his mission was to gather information regarding the physical condition of Central America and the political and moral state of its inhabitants. In particular, the chargé was "to observe the Country with reference to its future capabilities of a commerce, mutually advantageous, with the United States . . ." If any foreign power attempted to secure "peculiar concessions" for its commerce, he was to oppose such proceedings: all that the United States desired was "free competition." 77

During the first three decades of the nineteenth century, the colony of Brazil was establishing its independence of the motherland. In a sense this movement dates from the flight of the house of Braganza from Lisbon to Rio de Janeiro in 1807-1808 to ecape Napoleon's soldiers: thus from 1808 to 1821 the colonial city was the capital of the Portuguese dominions. Another step in this movement was the decree issued on December 16, 1815 , declaring that the colony of Brazil was a kingdom, which placed it upon the same basis as Portugal and Algarves. ${ }^{78}$ Then, on March 20, 1816, Queen Maria I, who had long been incapable of ruling, died: ${ }^{79}$ and her son John, who had been acting as regent, was formally proclaimed king of Portugal, Brazil, and Algarves on February $6,1818 .^{80}$ Further, at the invitation of the Portuguese cortes, in April, 1821, King John VI sailed from Rio de Janeiro for Lisbon, after declaring that his eldest son, Pedro de Alcantara, was prince regent of Brazil. Lastly, the reactionary policy of the Portuguese cortes, which passed decrees that much dissatisfied the Brazilians, stimulated a party in Brazil which favored separation from Portugal. Hence, in September, 1822, Prince Pedro formally proclaimed the independence of Brazil from Portugal. On October 12, 1822, Pedro was solemnly acclaimed constitutionả emperor of Brazil at Rio de

\footnotetext{
77 State department manuscripts, bureau of indexes and archives, Instructions to ministers, 10; for the treaty between the United States and Central America, see Malloy, Treaties between the United States and other powers, 1: 160-170. The appointment of Williams as chargé to the federation of Central America was confirmed by the senate on December 29, 1825. Senate executive journal, 3:461, 469.

${ }_{78}$ Colleção das leis do Brazil de 1815, pp. 63, 64; see further, J. Luccock, Notes on Rio de Janeiro and the southern parts of Brazil (London, 1820), 567-569.

79 M. de Oliveira Lima, Dom João VI no Brazil (Rio de Janeiro, 1908), 2 : 951.

80 Collecção das leis do Brazil de 1818, pp. 11-15; Luccock, Notes on Rio de Janeiro, 570-573.
} 
Janeiro. ${ }^{81} \quad$ Even before a constitution was proclaimed for the empire of Brazil, the ministers of Pedro I were trying to initiate diplomatic relations with the nations of Europe and America. ${ }^{82}$ On January 21, 1824, Luis de Carvalho e Mello, Brazil's minister of foreign affairs, appointed José Silvestre Rebello chargé d'affaires to the United States. ${ }^{83}$ The instructions of that envoy, dated January 31, 1824, urged him to ask for the recognition of the independence of the empire of Brazil by the United States. ${ }^{84}$

Soon after arriving in Washington, Rebello made Secretary Adams acquainted with the purpose of his mission. On April 5 Adams made an entry in his diary to the effect that he had received a note from Rebello announcing himself as chargé d'affaires from Brazil. ${ }^{85}$ On the following day the cabinet considered the question whether or not the independence of the empire of Brazil should be recognized by the reception of Rebello in his official capacity. Wirt doubted the expediency of such recognition, for the revolutionary government of Brazil was not republican but monarchical; Calhoun warmly favored the recognition of the independent government of Brazil, arguing that the United States had recognized the independence of the Mexican empire by receiving a minister from Agustín I; while President Monroe took the view that the recognition of the empire of Brazil would make the recognition of the independence of the Spanish-American states less offensive to the holy alliance. Adams held that there were stronger reasons for the acknowledgment of Brazilian independence than there had been for the recognition of SpanishAmerican independence, alleging that while the king of Portugal was residing in Brazil he "had proclaimed it an independent

81 For a detailed discussion of the movement which culminated in the independence of Brazil from Portugal, see M. de Oliveira Lima, Formation historique de la nationalité brésilienne (Paris [1911]), 151-168. J. M. Pereira da Silva, Historia da fundação do imperio brazileiro (Rio de Janeiro, 1870-1871), 3 : especially pp. 109-129.

82 The Brazilian constitution of 1824 is found in Collecção das leis do imperio do Brazil de 1824, pt. 1: 7-36; on the negotiations of Brazil with European powers, see M. de Oliveira Lima, $O$ reconhecimento do imperio (Paris, 1902).

83 Collecção das leis do imperio do Brazil de 1824, pt. $2: 4$.

84 A translation of Rebello's instructions is found in a pamphlet entitled "Brazil, the United States, and the Monroe doctrine"' (Washington, 1908), 8, 9, which is a translation of an article in $O$ jornal do commercio of Rio de Janeiro, January 20, 1908, that has been attributed to J. M. da Silva Paranhos Rio Branco.

85 Adams, Memoirs of J.Q. Adams, 6: 279, 280. 
kingdom." Secretary Adams proposed that he should secure from Rebello a statement of facts in regard to the condition of Brazil. ${ }^{86} \quad$ A short time afterwards in response to a request from the secretary of state, the Brazilian charge sent to Adams a note accompanied by an exposition of the events which led the Brazilians to declare themselves independent of Portugal. This exposition closed with a plea that the United States should recognize the independence of Brazil. In Rebello's note he expressed a hope that when his exposé was read, a day and an hour would be set for his presentation to the government of the United States. Further, he declared that the governments of France and England, which were seeking influence in the councils of Brazil, had proposed to recognize the independence of that state. He argued that the United States should oppose European influence in America; that that government should send diplomatic agents to the capitals of the Latin-American states; and that a diplomatic agent should be sent from Washington to Rio de Janeiro at once. Like Rebello's exposition, his note ended with a plea for the recognition of the independence of Brazil. ${ }^{87}$ On April 29 Rebello sent to Adams another note asking that the independence of the Brazilian empire should be recognized: on this occasion, he referred to the recognition of the independence of the Spanish-American states by the United States as constituting a precedent for the recognition of the independence of Brazil. ${ }^{88}$

Rebello's pleas for recognition were transmitted by Adams to Monroe, but unfavorable reports concerning the conditions at Rio de Janeiro apparently influenced Adams and Monroe to postpone action. When the Brazilian chargé was informed of the reasons for Monroe's delay in receiving him, he declared that there was no basis "for the suspicion that Brazil was not finally and irrevocably independent of Portugal." Again, the Brazil-

86 Adams, Memoirs of J. Q. Adams, 6: 281, 282.

87 Rebello's credentials, dated January 31, 1824, are found in state department manuscripts, bureau of indexes and archives, Notes from legations: Brazil, 1; Rebello to Adams, April 20, 1824, containing a "Succinct and true exposition of the facts that led the Prince, now Emperor, and the Brazilian People, to declare Brazil a free, and Independent Nation," ibid. See also A. Pereira Pinto, Apontamentos para o direito internacional ou collecção completa dos tratados celebrados pelo Brazil condiferentes naçãos estrangeiros (Rio de Janeiro, 1864-1865), 2 : 388.

88 Rebello to Adams, April 29, 1824, state department manuscripts, bureau of indexes and archives, Notes from legations: Brazil, 1. 
ian cited the action of the United States in regard to the revolted Spanish-American colonies. As Monroe believed that the essential factor was the independence of Brazil and felt that if the recognition of that state were delayed until after congress adjourned, some people might suppose that he had "purposely deferred it, to assume the authority of recognizing it without consulting congress," on May 22 Adams proposed to Monroe that Rebello should be formally received early in the following week. ${ }^{88}$ Accordingly, on May 25, Adams addressed a note to the Brazilian chargé informing him that he would "have the honour of presenting him in his character of Chargé d'affaires to the President of the United States, at one o'clock to-morrow, the 26th of May." ${ }_{90}$ On that day Secretary Adams formally presented Rebello to President Monroe as chargé d'affaires from Brazil :11 this ceremony constituted the recognition of Pedro I as emperor of Brazil by the United States.

On May 31 following, Joaquin Barrozo Pereira, chargé d' affaires of Portugal in the United States, addressed a letter to Adams protesting against the reception of Rebello. In his reply, dated June 9, 1824, Adams declared that this ceremony was "in no wise intended as an act unfriendly to the government or people of Portugal." He declared that it was "the recognition of a government existing in fact"; he affirmed that this government was ruling in a country which "his Majesty, the King of Portugal, had several years since, proclaimed as an Independent kingdom. . . ." He declared that differences between the European powers and their American colonies had never been encouraged by the United States.

"In recognizing as independent States, some of the countries which had been Spanish Colonies, they have done no more than has been done by his Majesty, the King of Portugal, himself. The recognition of the Independence of those States was, in no

89 Adams, Memoirs of J. Q. Adams, $6: 317-319,348$.

90 Adams to Rebello, May 25, 1824, state department manuseripts, bureau of indexes and archives, Notes to foreign legations, 3; A. Pereira Pinto, Apontamentos para o direito internacional ou collecção completa dos tratados celebrados pelo Brazil con diferentes naçãos estrangeiros, 2: 389.

91 Adams, Memoirs of J.Q. Adams, 6:358, 359; the National Intelligencer, May 28, 1824. With regard to the attitude of Brazil towards the Monroe doctrine at this juncture see Robertson, "South America and the Monroe doctrine," in Political science quarterly, 30:94-97. 
wise induced by any existing differences between the United States and Spain; nor was it deemed, in any manner incompatible with her sovereign rights. Such was the opinion of the Fortuguese Government itself, with reference to the Ex-colonies of Spain; and such, by an application of the same principles, must it ultimately be, as is presumed, with regard to its own relations with Brazil. . . . Faithful to the principle that every Independent people have the right to form, and to organize their Government as to them shall seem best, in the pursuit of their own happiness, and without encroaching upon the rights of others, they have recognized the Brazilian Government, as existing in fact, and exercising all the authorities essential to the maintenance of the usual relations between the United States and other foreign Independent Powers." ${ }_{92}$

Before the recognition of the independence of Brazil there had been a legation of the United States at Rio de Janeiro. ${ }^{9_{3}}$ On March 5, 1825, Condy Raguet was appointed chargé d'affaires of the United States to the empire of Brazil: on March 9, the senate confirmed the appointment, ${ }^{94}$ and on April 14, 1825, Henry Clay signed Raguet's general instructions. The chargé was directed "to lose no opportunity" to advance the interests of American commerce, while resisting any attempts by France and England to secure any commercial advantages which were not granted to the United States. Secretary Clay rightly declared that the United States was the first government to recognize the independence of Brazil: "The United States were the first to acknowledge that Government, disregarding all the risks incident to the fact, and to the nature of its recent establishment, and overlooking the anomaly of its political form in the great family of American Powers. The United States do not claim from this prompt and friendly measure, favor; but they insist upon equal justice to their commerce and navigation. And the

\footnotetext{
92 State department manuseripts, bureau of indexes and archives, Notes to legations, 3.

93 Thomas Sumter, Jr., of South Carolina had been minister plenipotentiary of the United States at Rio de Janeiro, Mareh 7, 1809-July 24, 1819; John Graham of Virginia, from January 6, 1819-July 31, 1820; and John J. Appleton of Massachusetts had been chargé d'affaires ad interim from June 10, 1820-1821, according to the Register of the department of state, 52 .

94 Senate executive journal, 3:437, 445.
} 
President is altogether unprepared to see any European State, running off with commercial advantages which shall be denied to an earlier and more uncalculating friend."

With regard to a commercial convention between the United States and Brazil, Clay declared that if the Brazilians strongly desired to negotiate a treaty at Rio de Janeiro, Raguet would be furnished with special instructions. Clay also referred to certain proposals which Rebello had made to the United States in regard to the application of the Monroe doctrine against Portugal, declaring that the decision of the United States not to intervene had been made in conformity with a policy of neutrality. Still, the chargé was instructed to suggest to the government of Brazil that it should maintain "in its correspondence and intercourse with the European Powers, the same principle which has been proclaimed here against the establishment, on this Continent, of new European Colonies." 95

On the very day when he received his credentials, November 26, 1824, Condy Raguet presented them to the government of Brazil. Two days later the Brazilian minister of foreign affairs informed Raguet that the emperor would receive him on the following day. Accordingly, on November 29, Raguet was formally received by Pedro I. At this time, following the example which had been set by the ministers of the United States to the independent nations of Spanish America, Raguet made an address to the chief executive which he considered "appropriate to the occasion"': in reply, the Emperor Pedro I merely thanked him. ${ }^{96}$

This study shows that by receiving diplomatic agents from Colombia and Mexico and by sending envoys to Buenos Aires, Chile, and Peru, the government of the United States carried out its policy formally to recognize the independence of the revolted Spanish colonies - a policy which President Monroe had recommended in his message to congress of March 8, 1822. In all, from 1822 to 1827, the United States accredited diplomatic agents to six Spanish-American states which were evidently in-

\footnotetext{
95 State department manuseripts, bureau of indexes and archives, Instructions to ministers, 10.

96 Raguet to Clay, November 12, 1825, state department manuscripts, bureau of indexes and archives, Despatches from ministers: Brazil, 4.
} 
cluded within the scope of the act of May 4, 1822. In accordance with the precedent established in regard to Spanish America, the colony of Brazil which had separated from Portugal, was also recognized by the United States as being independent of the mother-land. Thus, during a critical period in Hispanic history, the United States established legations in seven of the new states of Latin America. Contemporaneously, several of these states established legations at Washington. Although by her policy of recognition the United States had braved the anger of the holy alliance, yet she did not on that account ask favors from the new states: for example, our ministers were directed to solicit a square deal in commercial matters - nothing more and nothing less. Ignorant of the excitement which the decisive policy of the United States had provoked in the chancelleries of the continental allies, the significance of the acknowledgment of their independence by the great republic of the north was not sufficiently appreciated by statesmen throughout the SpanishAmerican republics. To adapt the phrase of that distinguished American publicist whose name is intimately associated with the diplomacy of his age, the formal interchange of diplomatic missions between the United States and Latin America constitutes a memorable event in the history of the American states - an event which laid the foundations for Pan-Americanism.

William Spence Robertson

University of IlLinois

URBANA 

Math

1
1

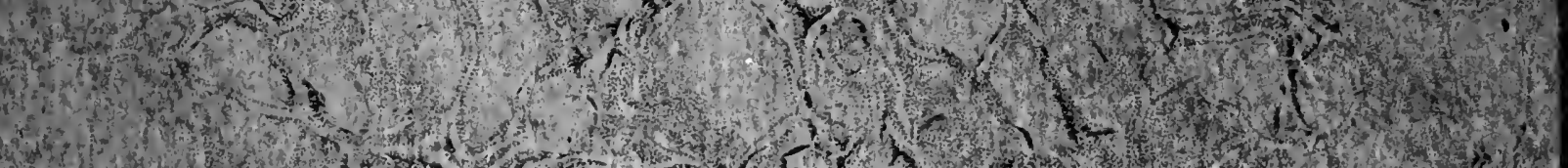

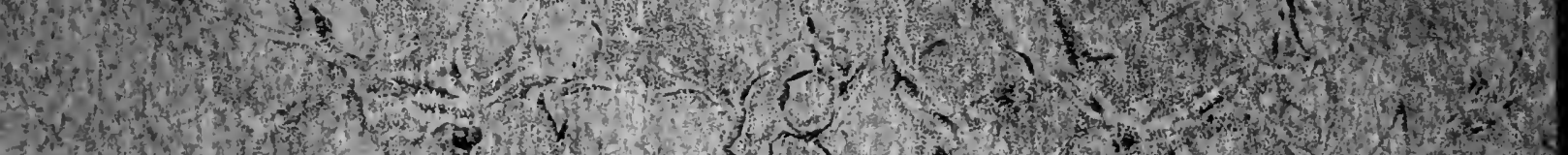

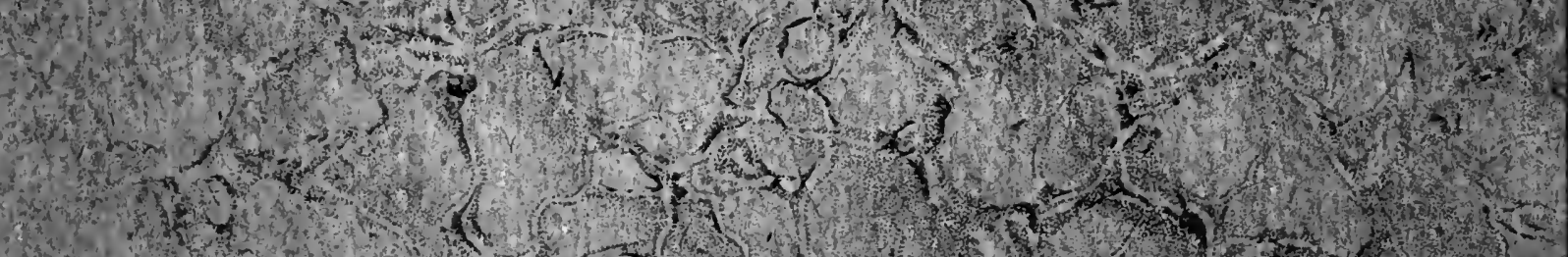

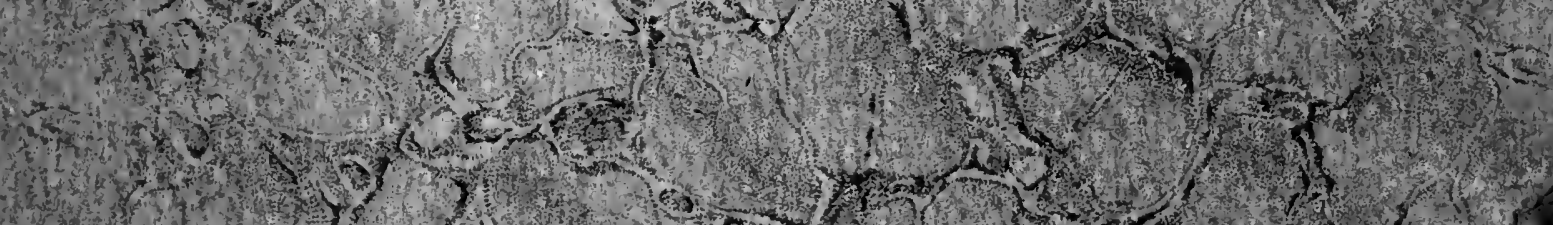

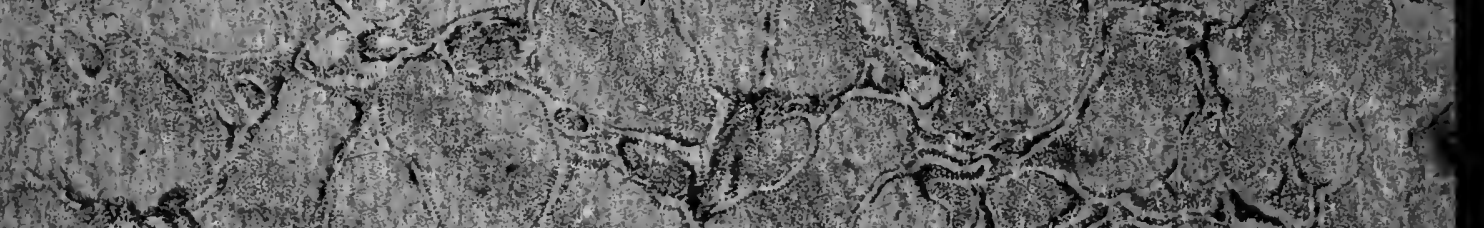

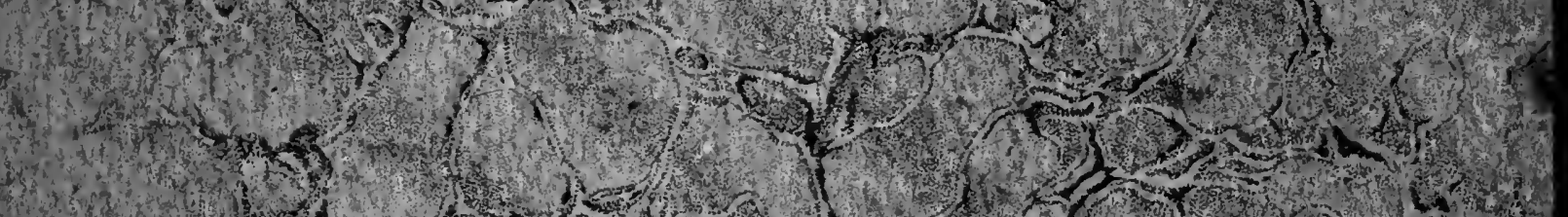

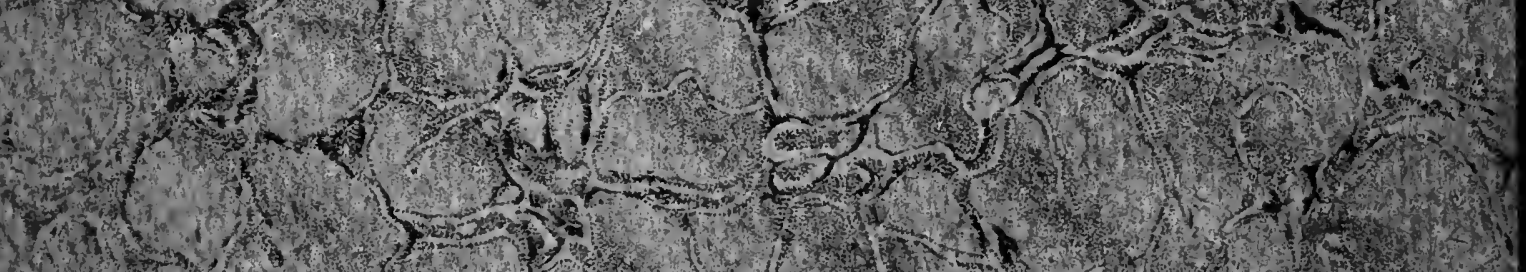

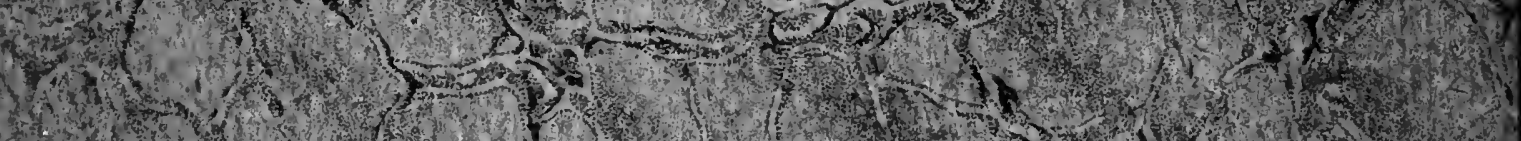

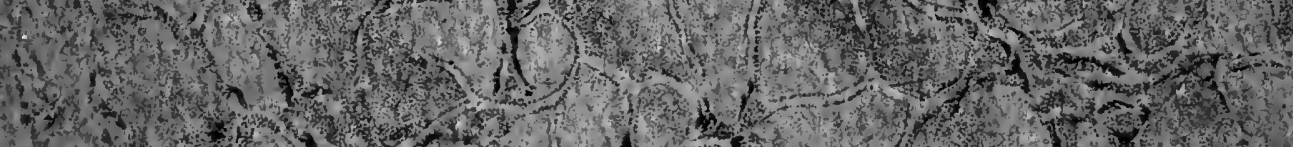

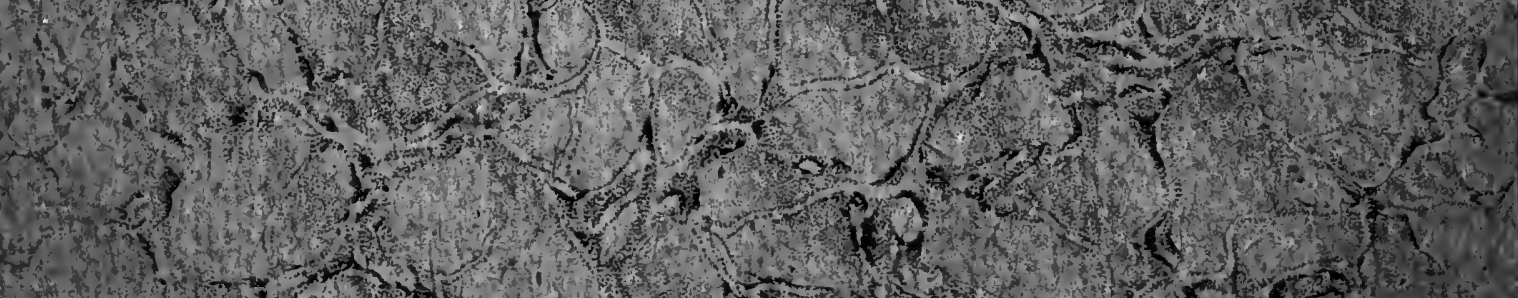

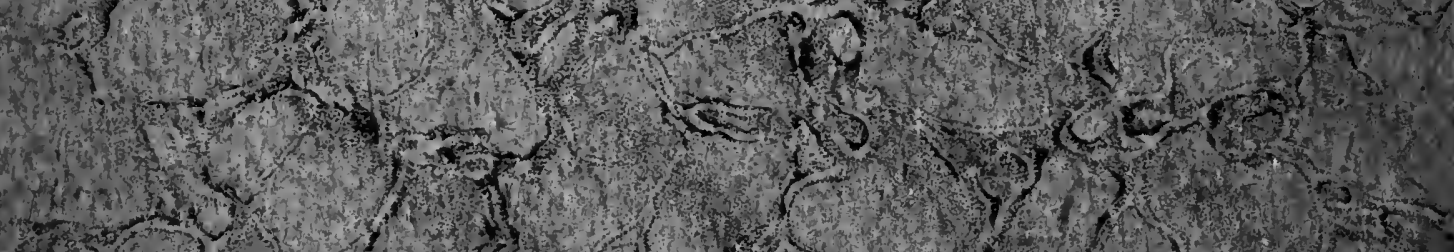

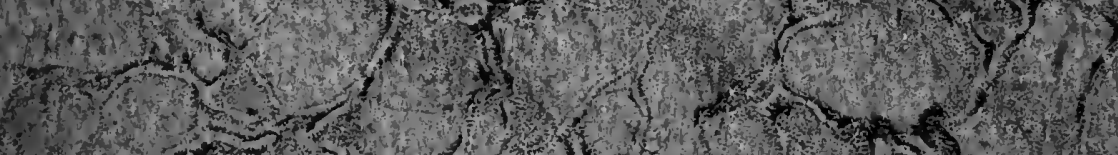

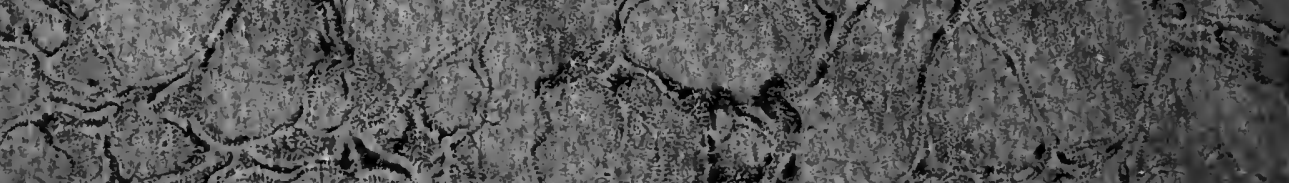

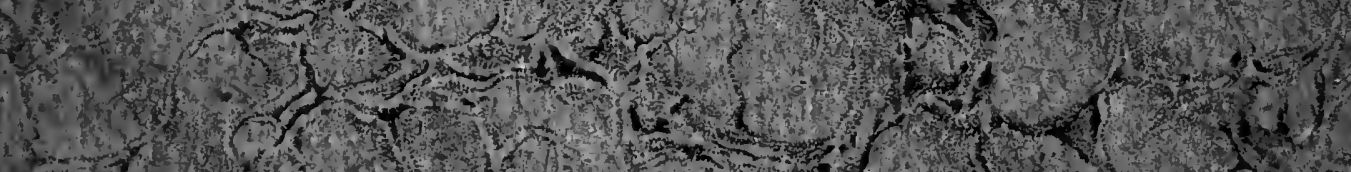

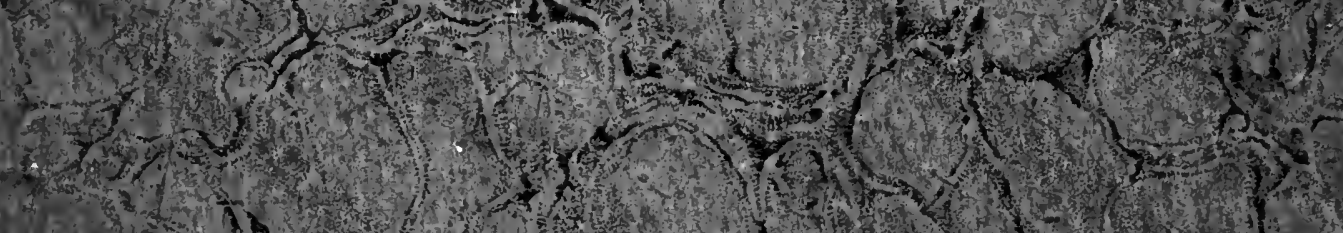

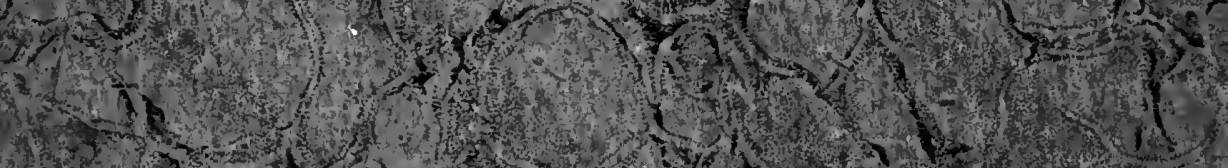

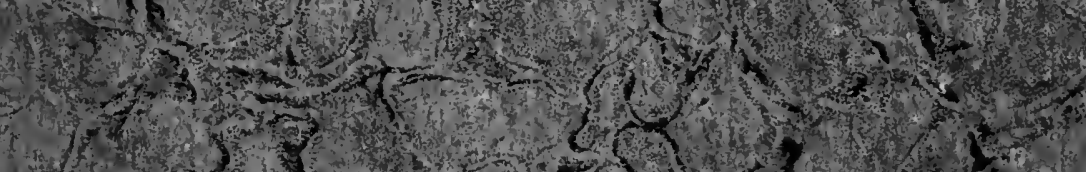
ger ter at 